\title{
CD133/prominin1 is prognostic for GBM patient's survival, but inversely correlated with cysteine cathepsins' expression in glioblastoma derived spheroids
}

\author{
Seyed Y. Ardebili ${ }^{1}$, Irena Zajc², Boris Gole², Benito Campos³ ${ }^{3}$ Christel Herold-Mende ${ }^{3}$, \\ Sara Drmota2,4, Tamara T. Lah2,4 \\ ${ }^{1}$ Department of Neurosurgery, University Medical Centre, Ljubljana, Slovenia \\ 2 Department of Genetic Toxicology and Cancer Biology, National Institute of Biology, Ljubljana, Slovenia \\ ${ }^{3}$ Division of Neurosurgical Research, Department of Neurosurgery, University of Heidelberg, Heidelberg, Germany \\ ${ }^{4}$ Department of Chemistry and Biochemistry, Faculty of Chemistry and Chemical Technology, University of Ljubljana, \\ Ljubljana, Slovenia
}

Received 27 February 2011

Accepted 11 April 2011

Correspondence to: Prof. Dr. Tamara T. Lah, National Institute of Biology, Večna pot 111, SI-1000, Slovenia. Phone: +386 59232703 ; Fax: +386 1241 2980; E-mail: tamara.lah@nib.si

Disclosure: No potential conflicts of interest were disclosed.

Introduction. CD133 is a marker for a population of glioblastoma (GBM) and normal neural stem cells (NNSC). We aimed to reveal whether the migratory potential and differentiation of these stem cells is associated with CDI33 expression and with cathepsin proteases (Cats).

Materials and methods. The invasiveness of normal NNSC, GBM/CD133+ cell lines and GBM spheroids was evaluated in 3D collagen, as well as of U87-MG and normal astrocytes (NHA) grown in monolayers in 2D Matrigel. Expression of Cats B, L and S was measured at mRNA and activity levels and their relation to invasiveness, to CD133 mRNA in 26 gliomas, and to the survival of these patients.

Results. The average yield of CD133+ cells from GBM samples was $9.6 \%$. Survival of patients with higher CD133 mRNA expression was significantly shorter ( $p<0.005)$. Invasion, associated with proteolytic degradation of matrix, was higher in normal stem cells and GBM spheroids and cells than in isolated GBM CD133+ cells. In glioma samples, there was no correlation between CD133 mRNA expression and Cat mRNAs, but there was an inverse correlation with Cat activities. Conclusions. The study confirms CD133 as a prognostic marker for the survival of GBM patients. We demonstrated that NNSC have higher invasion potential and invade the collagen matrix in a mode different from that of GBM, initiating stem cell spheres. This result could have implications for the design of new therapeutics, including protease inhibitors that specifically target invasive tumour stem cells. Increased activity of cathepsins in CD133- cells suggests their role in the invasive behaviour of GBM.

Key words: CD133/prominin 1; cysteine cathepsins; glioblastoma; glioma stem cells; invasion; neural stem cells

\section{Introduction}

Gliomas are the most abundant brain tumours, progressing from benign astrocytomas via anaplastic astrocytomas to the most malignant form, glioblastoma multiformae (GBM). The poor prognosis and short life expectancy for GBM patients is partly related to the high invasiveness of the tumour cells. In contrast to carcinoma, GBM cells infiltrate the nor- mal brain parenchyma as single cells, making this tumour extremely difficult to target by conventional therapy..$^{1-3}$ GBM is highly heterogenous, consisting of various types of cells. According to the hierarchical model of tumourigenesis, only a small fraction of tumour cells, the cancer stem cells (CSC), are capable of initiating tumour growth, and renewing the tumour in the same or other organ after incomplete surgical removal. ${ }^{4-6}$ When injected orthotopi- 
cally, these cells were phenotypically characterised as capable of self renewal, asymmetric division and tumour formation in animal models of the same growth characteristics. These cells are also highly resistant to chemo- or radio-therapy ${ }^{6,7}$ and presumably they and/or their immediate progenitors have high invasive potential to seed at a distance from the tumour. ${ }^{8}$

In a selective GBM stem cell population, plasma membrane associated protein CD 133/prominin-1 is considered as a cell surface marker of stemness and has been widely used for identifying putative stem cells from a variety of untransformed and cancerous tissues. However, CD133 is also expressed in differentiated epithelial cells in various organs, as well as in hematopoietic cells. ${ }^{9}$ From its first use for identification of cancer stem cells in brain tumours ${ }^{10}$, CD133 is still the most commonly used brain cancer stem cell marker, despite the many contradictions regarding the methods used to detect the expression of a surface marker in brain tumours. Some studies have shown that not all high grade gliomas express CD133 ${ }^{11}$ and also, that CD133 negative cell populations from GBM may have tumour initiating potential ${ }^{12}$, giving rise to CD133+ tumours. ${ }^{13-15}$ The role of this marker in further steps of tumour progression is not known.

Cancer stem cells are, presumably, not only associated with high resistance to therapy but also with higher invasion and metastatic potential, as proposed by Brabletz et al. ${ }^{8}$ Proteolytic enzymes, including lysosomal cathepsins, participate in many normal and pathological processes and have been associated with cancer progression, mostly with invasion. ${ }^{16-19}$ Cysteine cathepsins B, L and S (CatB, CatL and CatS) and the aspartic cathepsin $\mathrm{D}$ are over-expressed in many tumour tissues and cells, and have been reported to be mediators of glioma invasion. ${ }^{19-21}$ Cysteine cathepsins comprise the largest family of lysosomal enzymes, with 11 proteases structurally grouped in CatB-like and CatL-like enzymes (http://www.merops.ec.uk). ${ }^{22}$ We have demonstrated the prognostic impact of CatB, but not of CatL, on survival of glioma patients. $^{23,24}$ In vitro, we have recently confirmed the inhibition of the invasion of permanent GBM cell lines, as well as primary GBM spheroids by synthetic CatB inhibitors, emphasizing the role of CatB activity that was induced posttranslationally in the invasive GBM subpopulation. ${ }^{25}$

Although the homologous enzyme, CatL, is also correlated with glioma progression ${ }^{26-28}$, it appeared to be more relevant to proliferation and apoptosis than to the invasion process. ${ }^{29}$ Flannery et al. ${ }^{30}$ demonstrated that expression of CatS was an independent predictor of survival in GBM tumours, presumably also being related to invasion. However, the proteolytic efficacy of cysteine cathepsins is regulated at all levels of their expression, ultimately by their endogenous inhibitors, the cystatins (http://www.merops.ec.uk). ${ }^{22}$ Cystatin superfamily comprises two different families, cystatin family (with extracellular cystatins) and stefin family (with intracellular stefins), all these playing a role in cancer progression. ${ }^{17,31}$ A specific role for lysosomal cathepsins in stem cells biology has not been reported.

The first aim of the present study was to demonstrate CD133 mRNA expression in cancerous and normal neurospheres and GBM primary spheroids, and to assess whether there is any prognostic value of this marker for GBM patients treated with standard therapeutic protocols. Secondly, we aimed to establish whether there is any correlation between CD133 and the lysosomal cysteine cathepsins, CatB, CatL and CatS and their inhibitors stefin $B$ and cystatin $C$, at various levels of expression in these tumours. Finally, we were interested in correlation between proteolysis and the invasion of a variety of CD133 expressing normal and cancerous cells under in vitro conditions.

\section{Materials and methods}

\section{Glioblastoma patients}

The patients were operated at the Department of Neurosurgery, University Clinical Centre of Ljubljana, Slovenia. Tumour samples were collected from 26 patients (16 male, 10 female, median age 60 years, Table 1). 24 patients were diagnosed with WHO grade IV glioblastoma and the remaining two with WHO grade III anaplastic astrocytoma by standard histopathology protocols at the Institute of Pathology, Faculty of Medicine in Ljubljana. These patients were all treated by standard protocols as shown in Table 1. The study was approved by the National Medical Ethics Committee of the Republic of Slovenia (Approval no. 109, 204-6/10/07).

\section{Tumour samples and primary tumour culture preparation}

Immediately after removal from the patients, the tumour samples were placed in sterile ice-cold "stem cell buffer" (124 mM NaCl, $5.0 \mathrm{mM} \mathrm{KCl}$, $1.3 \mathrm{mM} \mathrm{MgCl}{ }_{2}, 2.0 \mathrm{mM} \mathrm{CaCl}{ }_{2}, 26 \mathrm{mM} \mathrm{NaHCO}$, 
TABLE 1. Patient characteristics, therapy and overall survival

\begin{tabular}{|c|c|c|c|c|c|}
\hline NIB No. & histopathol. diagnosis & Gender & Age & $\begin{array}{l}\text { Survival } \\
\text { (days) }\end{array}$ & Additional therapies \\
\hline AA 060726 & AA & female & 58 & 51 & NAT \\
\hline AA 080424 & AA & female & 34 & $* 463$ & ChT/RT + ChT + DITEM \\
\hline GBM 061206 & GBM & male & 80 & 215 & NAT \\
\hline GBM 070103 & GBM & male & 37 & 366 & $\mathrm{ChT} / \mathrm{RT}+\mathrm{ChT}+\mathrm{BCNU}$ \\
\hline GBM 070322 & GBM & female & 74 & 84 & NAT \\
\hline GBM 070402 & GBM & male & 74 & 60 & NAT \\
\hline GBM 070904 & GBM & female & 70 & 273 & ChT/RT \\
\hline GBM 071017A & GBM & male & 43 & 297 & ChT/RT + ChT + c.pr. \\
\hline GBM 071017B & GBM & male & 27 & 284 & $\mathrm{ChT} / \mathrm{RT}+\mathrm{ChT}$ \\
\hline GBM $071115 A$ & GBM & male & 48 & 371 & $\mathrm{ChT} / \mathrm{RT}+\mathrm{ChT}+\mathrm{BCNU}$ \\
\hline GBM 080107 & GBM & male & 68 & 110 & palRT \\
\hline GBM 080110 & GBM & male & 45 & $* 568$ & $\mathrm{ChT} / \mathrm{RT}+\mathrm{ChT}+\mathrm{BCNU}$ \\
\hline GBM 080129 & GBM & female & 78 & 125 & NAT \\
\hline GBM 080512 & GBM & female & 72 & $* 445$ & palRT \\
\hline GBM 080521 & GBM & male & 66 & 131 & $\mathrm{ChT} / \mathrm{RT}+\mathrm{ChT}+\mathrm{BCNU}$ \\
\hline GBM 080528 & GBM & male & 50 & 143 & ChT/RT \\
\hline
\end{tabular}

Histopathological diagnosis of the tumours: AA- anaplastic astrocytoma (WHO grade III), GBM- glioblastoma (WHO grade IV). Age: age of the patients at the time of the operation in years. Survival: survival of the patients after the first operation in days (*- the patients were still alive at the end of data collection). Additional therapy (all the patients were operated, most also received additional therapies): NAT - no additional therapy used, ChT/RT- standard combination of chemotherapy (temozolomide) and radiotherapy (60 Gy), ChT- standard chemotherapy repeated, BCNU- additional chemotherapy with bis-chloronitrosourea, c.pr.- complementary medicine program, palRT- palliative radiotherapy, DITEM- dose dense chemotherapy with temozolomide, AVA- additional chemotherapy with avastin, palRT- palliative radiotherapy.

$10 \mathrm{mM}$ D-glucose, $\mathrm{pH} 7.35$ ) and transferred on ice to the cell-culture laboratory within one hour post-operation. The samples were finely cut. One part of each tissue sample was processed for magnetic bioseparation and the rest used for RNA and protein sample preparation as described below. The cut tumour tissue was washed twice in $1 \times$ PBS (PAA, Austria) and resuspended in stem cell buffer with added $1.33 \mathrm{mg} / \mathrm{mL}$ trypsin, $0.67 \mathrm{mg} / \mathrm{mL}$ hyaluronidase and $0.20 \mathrm{mg} / \mathrm{mL}$ kinurenic acid (all Sigma-Aldrich, Germany). After 90 min of incubation at $35^{\circ} \mathrm{C}, 5 \% \mathrm{CO}_{2}>95 \%$ relative humidity with shaking, the samples were centrifuged for $10 \mathrm{~min}$ at $300 \times \mathrm{g}\left(20^{\circ} \mathrm{C}\right)$. The supernatant was removed and the tissue resuspended in DMEM/F12 medium (PAA, Austria), supplemented with $0.7 \mathrm{mg} / \mathrm{mL}$ ovomucoid (Sigma-Aldrich). The tissue was finely dissociated with a thin glass Pasteur pipette and the tissue suspension was filtered through a $40 \mu \mathrm{m}$ nylon mesh (BD Falcon, USA).

\section{Isolation of CD133+ glioblastoma cells}

The single-cell suspension obtained was ten fold diluted in erythrocyte lysis-buffer $(155 \mathrm{mM}$ $\mathrm{NH}_{4} \mathrm{Cl}, 10 \mathrm{mM} \mathrm{KHCO}{ }_{3}, 0.1 \mathrm{mM}$ EDTA), incubated for $5 \mathrm{~min}$ at $20^{\circ} \mathrm{C}$, and centrifuged for $10 \mathrm{~min}$ at $300 \times \mathrm{g}\left(20^{\circ} \mathrm{C}\right)$. The supernatant was removed and 
the cells resuspended in MACS buffer $(1 \times \mathrm{PBS}$ supplemented with $0.5 \% \mathrm{w} / \mathrm{v}$ BSA and $2.0 \mathrm{mM}$ EDTA, $\mathrm{pH} 7.2$ ).

The prepared erythrocyte-free tumour cell suspension was used for direct magnetic bioseparation of CD133+ cells with miniMACS System (Miltenyi Biotec, Germany) according to the manufacturer's protocol. The cell suspension was labelled with $\mathrm{CD} 133+$ MicroBeads in the presence of $\mathrm{Fc}_{\mathrm{C}}$ reagent (both Miltenyi Biotec) for $30 \mathrm{~min}$ at $4^{\circ} \mathrm{C}$, then diluted in 10×V MACS buffer, centrifuged for $10 \mathrm{~min}$ at $300 \times \mathrm{g}\left(20^{\circ} \mathrm{C}\right)$, and resuspended in $500 \mu \mathrm{L}$ MACS buffer. The cell suspension was applied to a magnetic separation column in a magnetic miniMAC$S^{\mathrm{TM}}$ Separation Unit. The CD133 negative fraction was eluted into a centrifuge tube without applying pressure. The separation column was then removed from the magnetic unit and the CD133+ fraction retained in the column washed out by applying pressure into a separate tube. The percentage of CD133+ cells in tumour samples was calculated as the ratio of the number of cells in the CD133+ fraction to the sum of the cells in the two fractions.

The efficacy of the separation was estimated by quantitative RT-PCR for CD133 as described below. Only separations in which the expression of CD133 mRNA was significantly higher in the CD133 positive fraction than in the negative fraction $(\mathrm{F} \geq 1.50)$ were considered successful, and taken into the study.

\section{Primary cultures of GBM biopsy}

Primary cultures of unsorted cells and their CD133cell populations from GBM samples 071017A and 071115 were prepared and grown as monolayers in DMEM/F12 medium, supplemented with $10 \%$ foetal bovine serum, $4 \mathrm{mM}$ L-glutamine, $1 \%$ penicillin/streptomycin (all PAA) and 1M HEPES (Sigma-Aldrich). GBM spheroids were prepared from human glioblastoma biopsies as described elsewhere. ${ }^{32}$ Tumour biopsies were finely cut, resuspended in an appropriate volume of medium and seeded on agar coated cell culture dishes in a complete cell culture medium containing DMEM High Glucose $(4.5 \mathrm{~g} / \mathrm{l})$, supplemented with $10 \%$ foetal bovine serum, $1 \%$ penicillin/streptomycin, $4 \mathrm{mM}$ L-glutamine (all PAA) and $0.4 \mathrm{mM}$ NEAA (Sigma-Aldrich). When the majority of the spheres reached $200 \mu \mathrm{m}$, they were dissociated by addition of $0.25 \%$ trypsin -EDTA (Invitrogen, USA). The cell suspension was centrifuged for $10 \mathrm{~min}$ at $300 \times \mathrm{g}, 10^{\circ} \mathrm{C}$. The supernatant was removed and the cells distributed to new dishes in 1:3 dilutions.
These cells started to form spheres after approximately $24 \mathrm{~h}$.

\section{Normal neural stem cells (NNSC)}

Neural stem cells were grown from subventricular zones of brain tissue collected post-mortem as described. ${ }^{33}$ The collection and use of brain tissue was approved by the Medical Ethics Committee of the Republic of Slovenia (156/07/09). The tissue samples were finely cut, degraded by trypsin $(0.13 \% \mathrm{w} / \mathrm{V}$ in water, Sigma-Aldrich) for $30 \mathrm{~min}$ at $37^{\circ} \mathrm{C}$. Degradation was then blocked by $1 \%$ foetal bovine serum in DMEM medium (both PAA). The tissue suspension was filtered through $40 \mu \mathrm{m}$ nylon mesh, centrifuged for $5 \mathrm{~min}$ at $300 \times \mathrm{g}$, and resuspended in $10 \mathrm{~mL}$ of neurobasal medium, supplemented by basic fibroblast growth factor bFGF (20 ng/mL), EGF $(20 \mathrm{ng} / \mathrm{mL})$, serum supplement B27 (all Invitrogen, USA), heparin (1U/mL; SigmaAldrich), $1 \%$ penicillin/streptomycin and $4 \mathrm{mM}$ L-glutamine (both PAA). NNSC were grown in the form of spheres on non-adhesive culture dishes (Sarstedt, Germany).

\section{Established cell lines}

Normal human astrocytes (NHA cells) and human glioblastoma cell line U87-MG were obtained commercially from Cambrex (USA) and American Type Culture Collection, respectively. Both cell lines were grown in monolayers in DMEM High Glucose $(4.5 \mathrm{~g} / \mathrm{l})$, supplemented with $10 \%$ foetal bovine serum, $1 \%$ penicillin/streptomycin and $4 \mathrm{mM}$ L-glutamine (all PAA). The NHA medium also contained $20 \mathrm{mM}$ HEPES (Sigma-Aldrich, Germany). Cells were harvested by $0.25 \%$ trypsin -EDTA (Invitrogen).

In addition we made use of two GBM stem-like cell cultures that were previously established at the Division of Neurosurgical Research, Heidelberg, Germany. These CD133+ GBM stem cell spheroids were grown from cells NCH644 and NCH421k, obtained as described by Campos et al. ${ }^{34}$, on non-adhesive culture dishes (Sarstedt) in serum-free DMEM/ F12 medium, $1 \%$ penicillin/streptomycin and $4 \mathrm{mM}$ L-glutamine (all PAA), supplemented by bFGF $(20 \mathrm{ng} / \mathrm{mL})$ and EGF $(20 \mathrm{ng} / \mathrm{mL})$ (both Invitrogen, USA), and BIT-supplement (Provitro, Germany).

All cells and spheroids were cultured under standard conditions at $37^{\circ} \mathrm{C}$ in humidified atmosphere with $5 \% \mathrm{CO}_{2}$. Unless otherwise specified, plastic-ware was purchased from Corning Costar Corporation, USA. 


\section{D invasion assay of monolayers in Boyden chambers}

Cells were tested for their invasion potential in a two dimensional invasion assay as described previously. ${ }^{29}$ Transwell chambers (Corning) with $8 \mu \mathrm{m}$ pores were coated on the upper surface with Matrigel (0.25 mg/mL, BD Bioscience, USA) and $10^{5}$ cells were seeded. Fibronectin and conditioned serum free medium were used as chemoatractants. After $21 \mathrm{~h}$ incubation, MTT (1-(4,5-dimethylthiazol-2-yl)-2,5-diphenyl tetrazolium bromide, (Sigma-Aldrich) at $0.5 \mathrm{mg} / \mathrm{mL}$ final concentration was added to each chamber. After $3 \mathrm{~h}$ at $37^{\circ} \mathrm{C}$, the formazan crystals that formed were collected separately from the upper and lower chambers, pelleted and dissolved in dimethyl sulphoxide, and the absorbance at $570 \mathrm{~nm}$ (reference filter $690 \mathrm{~nm}$ ) measured on a spectrofluorimeter (Tecan). The percentage of cells penetrating Matrigel (invasive cells) was calculated as the ratio of the number of cells in the lower compartment to the sum of cells in both compartments. Invasion was normalised to that of normal neural stem cells NNSC.

\section{D invasion assay of spheres}

Spheroids of NNSC, CD133+GBM stem cells NCH644 and NCH421k and GBM biopsy spheroids were tested for proliferation and invasive potential as described previously. ${ }^{25}$ Spheres (150-300 $\mu \mathrm{m}$ in diameter) were embedded in $50 \mu \mathrm{L}$ drops of type I collagen matrix $(1.0 \mathrm{mg} / \mathrm{mL}, \mathrm{BD}$ Bioscience). After incubating for $30-45 \mathrm{~min}$ at $37^{\circ} \mathrm{C}$, the collagen was covered with cell culture medium. The spheroid diameter and cell invasion distance were measured under a light microscope using an ocular micrometer. Invasion distance was defined as the distance from the edge of the spheroid to the population of the cells most distant from the spheroid. Invasion was monitored for up to 21 days. Cell culture medium was changed every 3 days.

\section{DQ collagen degradation}

Matrix degradation is one of the important features of the invasion process. To test the ability cells and spheroids to degrade the extracellular matrix, fluorescently labelled type IV collagen (DQ collagen IV, Invitrogen) was added to a Matrigel matrix $(8.5 \mathrm{mg} / \mathrm{mL})$. The spheroids were imbedded into 50 $\mu \mathrm{L}$ drops of Matrigel with $1 \%$ DQ collagen IV as for the 3D invasion assay, whereas the cells grown in monolayer were plated on Lab-Tek Chamber Slides (Nunc, USA) pre-coated with Matrigel mixed with $2.5 \%$ DQ collagen IV. After $24 \mathrm{~h}$ incubation, the green fluorescence of degraded DQ collagen IV was observed under a Zeiss LSMS10 confocal microscope. To visualise the cells/spheroids the visual light pictures of the same areas were superimposed.

\section{Quantitative real-time PCR}

Samples were homogenized in TRIzol reagent (Invitrogen) and RNA isolated as suggested by the manufacturer. $1.0 \mu \mathrm{g}$ of each RNA sample was reverse transcribed to cDNA using High Capacity cDNA Reverse Transcription Kit (Applied Biosystems, USA) following the manufacturer's protocol.

Quantitative real-time-PCR assays were performed on ABI Prism 7900 HT Sequence Detection System using TaqMan Universal PCR Master Mix. Human GAPDH was used as internal control (all Applied Biosystems). Forward, reverse primers and probes sequences (in this order) were as follows: for CatB: 5'-CTC TATg AAT CCC ATg Tag ggT gC-3', 5'-CCT gTT TgT Agg TCg ggC Tg-3' and 5'-CCC TgT gAg CAC CAC gTC AAC gg-3'; for CatL: $5^{\prime}$-TCA ggA ATA Cag ggA Agg gAA A-3', 5'-TCC Tgg gCT TAC ggT TTT gA-3' and 5'CAC Tgg TCA TgT CTC CAA Agg CgT TCA T-3'; for StefA: 5' -ggA ggC TTA TCT gAggCC AAA-3', 5'-CAA gCT gTg gTT TAA CCT TAT CAA CA-3' and 5'-CCg CCA CTC CAg AAA TCC Agg AgA3'; for StefB: 5'-gCC gAg ACC CAg CAC ATC-3, 5'-ggC CTT AAA CAC Agg gAA CTT CT-3 and 5'-ACC Agg TgA ggT CCC AgC TTg AAg AgA-3; for CysC: 5'-gAC AAC TgC CCC TTC CAT gA3, 5'-gCA CAg CgT AAA TCT ggA AAg A-3 and 5'-CAg CCA CAT CTg AAA Agg AAA gCA TTC Tg-3. The probes were 5'-FAM 3'-TAMRA modified. For CD133 (PROM1), Hs00195682_m1 and for CatS, Hs00175403_m1 TaqMan Gene Expression Assays (both Applied Biosystems) were used.

Due to the low expression of the CD133 mRNA, the pre-amplification step was performed before quantitative RT-PCR using the PreAmp Master Mix (Applied Biosystems) as suggested by the manufacturer.

mRNA data were calculated as $2^{-\Delta \Delta C t}$ values. Fold differences in mRNA expression levels $(\mathrm{F})$ between CD133+ and CD133- populations were calculated as in Demuth et al. ${ }^{35}$, where $\mathrm{F}=2^{(\Delta \mathrm{CtCD} 133+-\Delta \mathrm{CtCD} 133-)}$ and $\mathrm{Ct}_{\mathrm{CD} 133+}=\mathrm{Ct}_{\mathrm{GAPDH}}-\mathrm{Ct}_{\text {target gene }}$ in the CD133+ cell population, and $\mathrm{Ct}_{\mathrm{CD133-}}=\mathrm{Ct}_{\mathrm{GAPDH}}-\mathrm{Ct}_{\text {target gene }}$ in the CD133- cell population. $\mathrm{F} \geq 1.50$ is considered as significantly higher and $\mathrm{F} \leq 0.75$ lower expression of the selected gene in CD133+ cells. F values be- 
tween 1.50 and 0.75 are regarded as non-significant differences.

\section{Protein extraction and enzyme activity assays}

Cells, grown in spheres were homogenized by sonication for $2 \mathrm{~min}$ in $50 \mathrm{mM}$ Tris buffer, $\mathrm{pH}$ 6.9, supplemented with $0.05 \%(\mathrm{~V} / \mathrm{V})$ Brij 35, $0.5 \mathrm{mM}$ dithiothreitol, $5 \mathrm{mM}$ EDTA, $0.5 \mathrm{mM}$ paramethylsulphonyl fluoride and $10 \mathrm{mM}$ pepstatin A (all Sigma-Aldrich). The homogenates were centrifuged for $30 \mathrm{~min}$ at $12.000 \times \mathrm{g}\left(4^{\circ} \mathrm{C}\right)$ and the supernatants stored at $-80^{\circ} \mathrm{C}$ until used.

CatB and CatL activities were measured as described previously. ${ }^{25}$ Duplicates of water diluted protein samples were supplemented with activation buffer $(0.4 \mathrm{M}$ phosphate buffer $\mathrm{pH}$ 6.0, $2.5 \mathrm{mM}$ fresh ditiothreitol for CatB; $0.34 \mathrm{M}$ acetate buffer, pH 4.2, $2.0 \mathrm{mM}$ fresh DTE for CatL; all Sigma-Aldrich) and incubated for $30 \mathrm{~min}$ at $37^{\circ} \mathrm{C}$. To measure specific cathepsin activity, water was added to one of the duplicates and specific in-

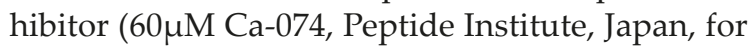
CatB; $2 \mu$ M Clik 148, provided by N. Katunuma, Tokushima Bunri University, Tokyo, Japan, for CatL) to the other. Activity buffer $(0.4 \mathrm{M}$ phosphate buffer $\mathrm{pH}$ 6.0, $2.5 \mathrm{mM}$ fresh DTE for CatB; $0.34 \mathrm{M}$ acetate buffer $\mathrm{pH} 5.5$, fresh $2.5 \mathrm{mM}$ DTE for CatL; all Sigma-Aldrich) was then added and the reaction started by adding specific substrate (100 $\mu$ M Z-RR-AMC for CatB, $100 \mu \mathrm{M}$ Z-FR-AMC for CatL; both Bachem, Switzerland). After $90 \mathrm{~min}$ at $37^{\circ} \mathrm{C}$ the reaction was stopped with $1 \mathrm{mM}$ iodoacetic acid and the released 7-AMC measured on a spectrofluorimeter (Tecan). Specific cathepsin activity was calculated as the difference in 7-AMC release in the presence and the absence of the specific cathepsin inhibitor.

CatS activity was measured as described by Flannery et al. ${ }^{30}$ Water diluted protein samples were supplemented with inactivation buffer (100 mM phosphate buffer, $\mathrm{pH} 7.5$ ) for $60 \mathrm{~min}$ at $37^{\circ} \mathrm{C}$ to fully inactivate $\mathrm{CatB}$ and $\mathrm{CatL}$. The $\mathrm{pH}$ was then returned to 6.0 using $500 \mathrm{mM}$ MES buffer. Reaction buffer (200 mM MES, $200 \mathrm{mM}$ EDTA, pH 6.0, fresh 1 mM DTT, all Sigma-Aldrich) was added and the reaction started by adding specific substrate $(100 \mu \mathrm{M} Z$ Z-VVR-AMC, Peptide Institute). After $90 \mathrm{~min}$ at $37^{\circ} \mathrm{C}$ the reaction was stopped with $100 \mathrm{mM}$ acetate buffer, $\mathrm{pH} 4.3$ and the released 7-AMC measured on a spectrofluorimeter.

Each activity assay was performed in triplicate, with controls with omitting the sample. Specific activities were expressed in enzyme units (E.U.) per $\mathrm{mg}$ of total protein, with one E.U. being the amount of the enzyme releasing $1 \mathrm{~nm}$ of 7-AMC per minute.

\section{Statistical analysis}

All statistical analysis was performed with Excel 2002 (Microsoft Corp., USA) and Prism 5.01 (GraphPad Software Inc., USA). The statistical significances of the differences observed were calculated as standard t-test with assumed two-tailed distribution and unequal variance. For correlation studies, Spearman's nonparametric method was used. Prognostic impact of CD133 expression for patient survival was calculated by relating it to overall survival by the Kaplan-Meier univariate analysis. To assess the association between survival period (from initial operation of the tumour to death of the patient) and other variables the Gehan-Breslow-Wilcoxon test was used.

\section{Results}

\section{Prognostic value of CD133 mRNA in human GBM}

Patient characteristics and survival after the operation are summarised in Table 1. 24 patients were diagnosed with WHO grade IV glioblastoma. In 19 of these, CD133+ mRNA expression in GBM tumour samples was compared with overall survival to assess the prognostic impact of CD133 mRNA (Figure 1). Survival of patients with higher CD133 mRNA levels $\left(2^{-\Delta \Delta C t}>30.000\right)$ was significantly shorter (median 81 days) than that of patients with lower CD133 mRNA levels (median 284 days, $p$ 0.005).

\section{Separation of CD133+ and CD133- cell populations from GBM samples}

The cell suspensions prepared from GBM samples were subjected to direct magnetic bioseparation. In 15 samples the separation was successful, based on the difference in the CD133 mRNA expression being at least 1.5 time higher $(F \geq 1.50)$ in the CD133+ than in the CD133- fraction (see Materials \& Methods). Only such samples were included in the further analysis. The abundance of the CD133+ cell fractions ranged from $2.0 \%$ to $38.8 \%$ of atotal cell population in individual tumour samples with an average of $9.6 \pm 9.5 \%$. 


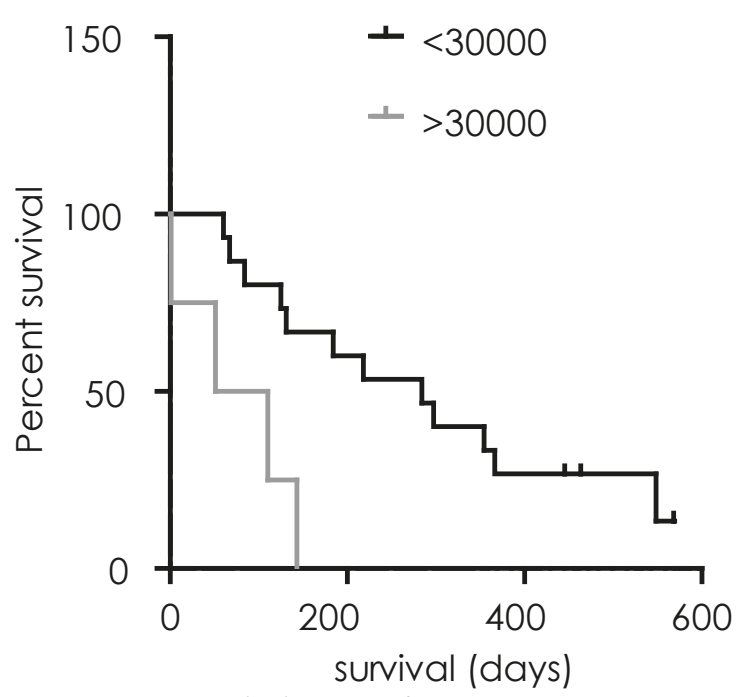

FIGURE 1. Prognostic impact of CDI33 mRNA level on survival of the patients. CD133 mRNA expression was measured by QRT PCR in glioma samples of 19 patients and compared to their survival time post-operation. Survival of patients with higher CD133 mRNA levels above a cut-off of 30000 (-, $\left.2^{-\Delta \Delta C t}>30.000\right)$ was significantly shorter (median 81 days) than survival of patients with CD133 mRNA levels below the cut off $\left(-, 2^{-\Delta \Delta C t}<30.000 ;\right.$ median 284 days, $\left.\mathrm{p}=0.005\right)$.

$\square$ CD133+ $\square$ CD133-/CatB $\square$ CD133-/CatL $\square$ CD133-/CatS

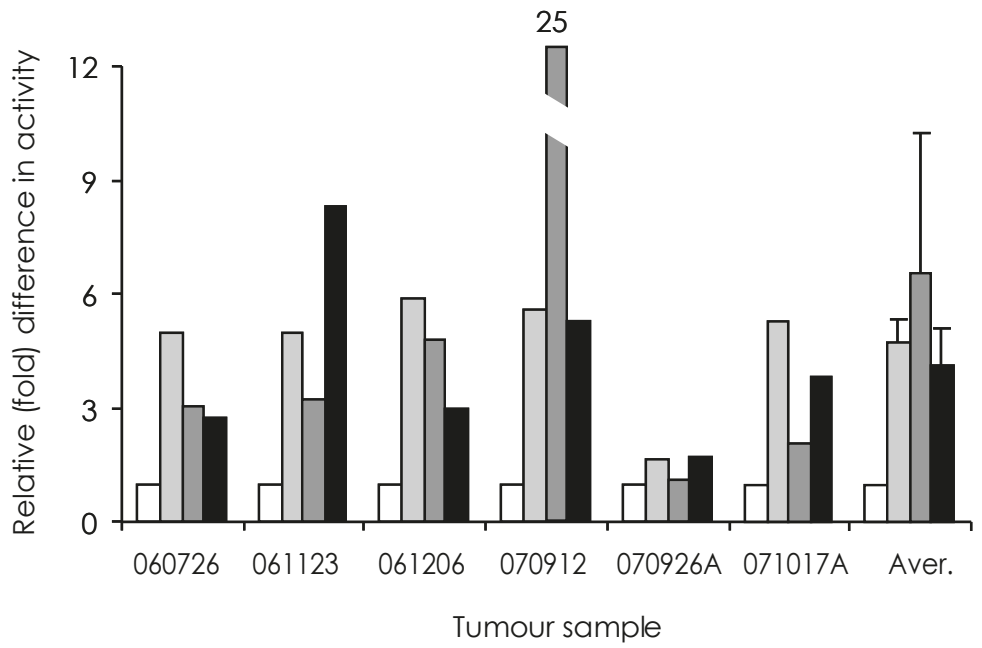

FIGURE 2. Differences in cathepsins' activities in CD133+ and CD133- cell fractions. In each of the six GBM samples, a relative activity of 1 was assigned to all the CD133+ cell fractions (white bars). Fold differences in activity of cathepsins between CDI33 and CD133+ cell fractions were calculated as described in Material and Methods. CatB activity (light grey bars) was 1.7-5.9 times (average 3.9) higher, CatL activity (dark grey bars) 1.1-25 times (average 2.6) higher and CatS activity (black bars) 1.78.3 times (average 3.2) higher in the CD133- cell fractions than in CD133+ fractions.

\section{Comparison of CD133 with other tumour markers at mRNA levels}

In mRNA extracts of CD133+ vs CD133- cells from 13 GBM patients we also compared the expression of other genes characteristics of neural and glioma cancer stem cells and their progenitors, such as nestin, and the markers for more differentiated cells, such as glial fibrillar acidic protein (GFAP) indicating astrocyte lineage differentiation, and $\beta$-tubulin 3 ( $\beta$-TUB 3), the marker of neural differentiation. Table 2A shows that there was no correlation of their expression with CD133 within the group of samples.

\section{Comparison of CD133 with cathepsin expression at the mRNA level}

In mRNA extracts of CD133+ vs CD133- cell fractions from 13 GBM patients we also measured mRNA levels of CatB, CatL, CatS, StefA, StefB and CysC (Table 2B). There was no significant correlation between these values. However, we observed that, in more than half the samples, the ratios of expression of $\mathrm{CD} 133+$ to $\mathrm{CD} 133^{-}$are lower $(\mathrm{F} \leq 1)$ in the three cathepsins. A similar trend was observed for the stefins, but an opposite one for cystatin C, for which increased levels in CD133+ samples were observed. This indicates that expression of the cathepsins increases with differentiation of CD133+ stem cells into the mature GBM cells.

\section{Cathepsin activity in CD133+ and CD133- cell populations}

In 6 tumour samples sufficient cellular material was obtained from the successful separation of CD133+ and CD133- cell fractions to assay cathepsin activities. In all the samples, CD133+ cell fractions contained significantly lower CatB, CatL and CatS activities than the CD133- cell fractions (Figure 2).

In parallel to their mRNA expression, the activities of $\mathrm{CatB}$ and $\mathrm{CatL}$ were higher, by $25 \%$ and $37 \%$, in the spheroids of NNSC than in GBM stem cells NCH644.

\section{Relative expression of cathepsins and CD133 in various cell lines in vitro}

Due to the very high variability of CD133 mRNA measurements, the difference between its concentrations in the spheroids of NNSC and NCH644 cells was not significant. In primary cell cultures of two GBM samples, CD133 mRNA expression was similar in unsorted GBM cell populations, but below the limit of detection in CD133- cells remaining after CD133+ cell separation (Figure 3A).

CatB and CatL mRNA expression are presented in Figure 3B. NNSC expressed 7-fold and 18-fold 
higher levels of CatB and CatL than the GBM stem cells NCH644. The expression of Cats B and L in primary GBM samples was similar to or nonsignificantly higher than that in NNSC. However, there was no consistent difference in cathepsin expression in unsorted GBM and CD133 cells from the same GBM samples.

\section{Invasion assays}

\section{D invasion assay}

Normal NNSC and NHA cells and the GBM cells NCH644 and U87-MG, unsorted, and their respective CD133- cell populations from GBM samples, were tested for invasive potential in a two dimensional (Boyden chamber) invasion assay. The results were normalised to the invasiveness of NNSC (Figure 3C). Unsorted GBM cells were always more invasive than the CD133- cell population from the same tumour. Interestingly, NNSC exhibited higher invasive potential than the GBM stem cells CD133+ NCH644, and NHA appeared to be more invasive than the malignant U87-MG cells, although the differences were not significant. These data correlate approximately with the expression of Cats B and L (Figure 3B).

\section{D invasion assay in collagen type I}

The invasion and proliferation of the spheroids of NNSC, GBM stem cells and GBM biopsy spheroids were monitored in a 3D assay (Figure 4 ). The mode of invasion of NNSC spheres differed from that of the GBM stem cells. The average invasion distance after 21 days in collagen was $1359 \pm 216 \mu \mathrm{m}$ for spheres of NNSC and $253 \pm 95 \mu \mathrm{m}$ for spheres of GBM stem cells (Figure 4A). The NNSC proliferate slowly, with the size of their spheroids decreasing slightly throughout the experiment (from $170 \pm 26 \mu \mathrm{m}$ to $153 \pm 27 \mu \mathrm{m}$, Figures $4 \mathrm{~B}$ and $\mathrm{C}$ ). In contrast, the spheroids of GBM stem cells NCH644 and NCH421k all grew in size from about $200 \mu \mathrm{m}$ to an average of $598 \pm 340 \mu \mathrm{m}$ (Figure $4 \mathrm{~B}$ and D). The high S.D. was due to the variation observed among individual spheroids; about half of them grew to a diameter of over $800 \mu \mathrm{m}$ in 21 days, whereas the others appeared to proliferate only in the first week of the experiment. The invasiveness of GBM biopsy spheroids appeared very limited; only a few cells invaded the surrounding collagen matrix, and we observed almost no change in spheroid size (Figure 4E). Due to adhesive interactions, GBM spheroids, containing a heterogeneous cell popula-

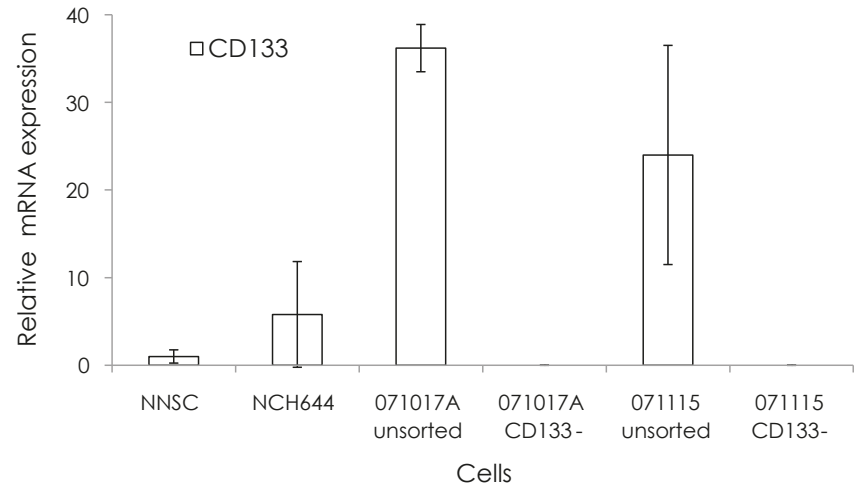

(A)

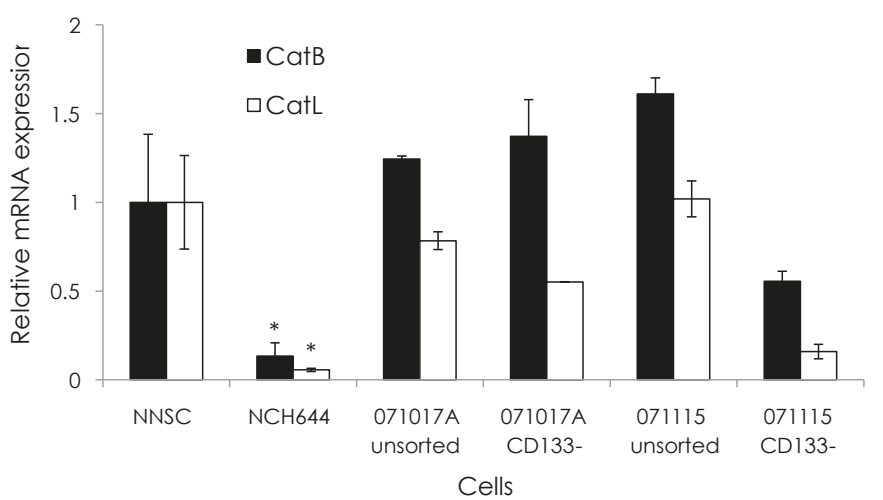

(B)

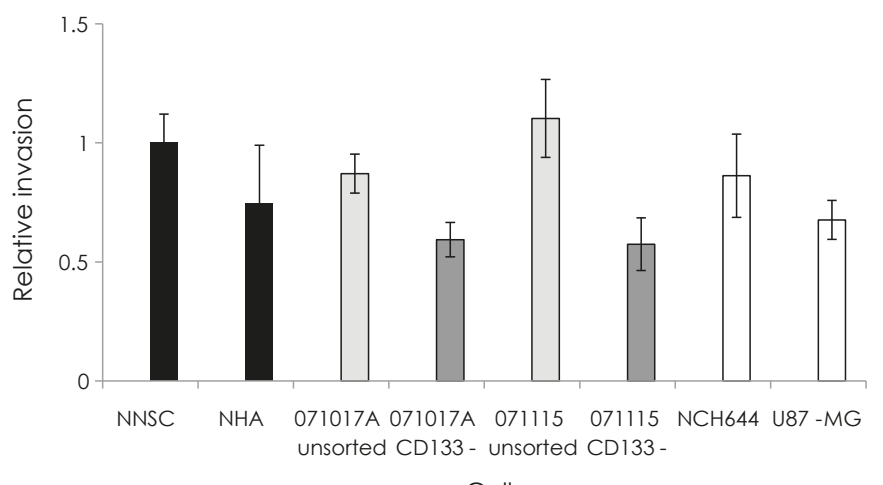

\section{Cells}

FIGURE 3. Correlation between expression of cathepsins and 2D invasion in Matrigel. CD133 mRNA expression in vitro. CD133 mRNA expression was determined by QRT PCR in NNSC and NCH644 spheroids, and in unsorted GBM samples and in CD133fractions from same GBM samples. A relative mRNA expression of 1 was assigned to NNSC. Cancer stem cells NCH644 cells were positive for CD133, however CD133 expression in (unsorted) GBM neurospheres was significantly higher (Student $t$-test, $\mathrm{p}<0.05$ ) in spite of high variability between the three independent cell cultures, whereas in CD133- fractions from the same tumours, CD133 mRNA was below the detection limit. Cathepsin B and Cathepsin L mRNA expression in vitro. Cathepsin $B$ and Cathepsin L mRNA expression was determined by QRT PCR in NNSC and NCH644 spheroids, and unsorted GBM samples and CD133-fractions from the same GBM samples. Relative mRNA expressions of 1 were assigned to NNSC. Cancer stem cells NCH644 cells expressed CatB and CatL at a significantly lower level than the NNSC (Student $t$-test, $p<0.05$ ). Two dimensional cell invasion. Two dimensional cell invasion of NNSC, NHA, unsorted GBM cells and CD133 GBM cell populations, NCH644 and U87-MG cells, into Matrigel was carried out as described in Material and Methods. The percentage of invasive cells in NNSC was adjusted to 1 and other values were expressed as invasion relative to NNSC cells. The high variability in three independent experiments is reflected by relatively high inter assay S.D. values, whereas within each experiment the S.D. was always less than $10 \%$. 
TABLE 2. A: Correlation between CDI33 and other differentiation markers

\begin{tabular}{lcccc}
\hline \multirow{2}{*}{$\begin{array}{l}\text { Tumour } \\
\text { Samples (n=13) }\end{array}$} & \multicolumn{4}{c}{$\mathbf{F}$} \\
\cline { 2 - 5 } GBM 061123 & $\mathbf{3 , 1 9}$ & $\mathbf{1 , 4 6}$ & $\mathbf{0 , 6 6}$ & $\mathbf{1 , 6 6}$ \\
GBM 061206 & $\mathbf{3 2 , 9}$ & $\mathbf{2 , 2 7}$ & $\mathbf{2 , 4 8}$ & 0,92 \\
GBM 070103 & $\mathbf{2 , 6 5}$ & $\mathbf{2 , 0 3}$ & $\mathbf{1 , 5 3}$ & $\mathbf{1 , 3 6}$ \\
GBM 070402 & $\mathbf{3 , 4 3}$ & $\mathbf{0 , 6 5}$ & $\mathbf{0 , 2 0}$ & 0,98 \\
GBM 070904 & $\mathbf{6 , 8 2}$ & $\mathbf{0 , 5 9}$ & $\mathbf{1 , 2 2}$ & $\mathbf{0 , 4 6}$ \\
GBM 070912 & 4,85 & 2,80 & 3,21 & 0,69 \\
GBM 070926A & $\mathbf{2 , 3 4}$ & $\mathbf{1 , 0 9}$ & $\mathbf{1 , 3 6}$ & $\mathbf{1 , 0 8}$ \\
GBM 070926B & $\mathbf{1 , 6 6}$ & $\mathbf{0 , 7 0}$ & $\mathbf{0 , 6 8}$ & $\mathbf{1 , 1 3}$ \\
GBM 071017A & $\mathbf{3 , 6 7}$ & $\mathbf{1 , 0 2}$ & $\mathbf{2 , 0 2}$ & $\mathbf{1 , 4 2}$ \\
GBM 071017B & 5,14 & 5,72 & 3,48 & 2,05 \\
GBM 071115A & $\mathbf{5 , 5 5}$ & $\mathbf{2 , 1 8}$ & $\mathbf{4 , 7 4}$ & 0,91 \\
GBM 080110 & $\mathbf{5 , 6 0}$ & $\mathbf{0 , 9 4}$ & $\mathbf{1 , 9 8}$ & $\mathbf{0 , 1 2}$ \\
GBM 080512 & $\mathbf{2 , 1 1}$ & $\mathbf{1 , 9 9}$ & $\mathbf{1 , 4 6}$ & 0,80 \\
\hline
\end{tabular}

tion, were less invasive than established cultured cells. Taken together, these data show that cell proliferation is higher in cancerous cells, and that invasion and proliferation appear to be inversely correlated.

\section{DQ collagen degradation}

The ability of NNSC, GBM stem cells, GBM biopsy spheroids, and the permanent cell lines U87-MG and NHA to degrade the extracellular matrix was demonstrated by breakdown of DQ collagen, monitored by green fluorescence (Figure 5). In spheroids of NNSC, green fluorescence, indicating matrix degradation, was dispersed radially from the sphere centre, most propably along the migration paths of the cells leaving the sphere (Figure 5A). In spheroids of CD133+ GBM stem cells, the cells had not migrated from the sphere after 24 hours, and matrix degradation was localized to small areas on the surface of the sphere (Figure 5B). In GBM biopsy spheroids, the green fluorescence was dispersed over the whole surface of the spheroid (Figure 5C). When grown in monolayers, fluorescence was less intense and more dispersed in GBM cells U87-MG (Figure 5D) than in the normal human astrocytes NHA (Figure 5E). This shows that, in spite of significantly different patterns and rates of invasion between normal and cancer SC and between more differentiated normal and cancer cells, the process involves proteolysis. This may be more extracellular in normal neural cell spheroids and to a larger extent intracellular in tumour cells at the GBM spheroid surface.

\section{Discussion}

Transmembrane protein CD133, alone or in combination with other markers, is the most common marker of stem cells in glioma. In this study, $\mathrm{CD} 133+$ cells were isolated from the most malig-

TABLE 2. B: Correlation between CDI33 and expression of cathepsins and stefins

\begin{tabular}{|c|c|c|c|c|c|c|c|}
\hline \multirow{2}{*}{$\begin{array}{l}\text { Tumour } \\
\text { Samples }(n=13)\end{array}$} & \multicolumn{7}{|c|}{$\mathbf{F}$} \\
\hline & CD133 & CatB & CatL & Cats & StefA & StefB & CysC \\
\hline GBM 061123 & 3,19 & 0,40 & 0,13 & 0,20 & 0,09 & 0,61 & 1,33 \\
\hline GBM 061206 & 32,9 & 1,60 & 2,50 & 3,87 & 1,73 & 1,35 & 1,28 \\
\hline GBM 070103 & 2,65 & 0,88 & 0,92 & 1,00 & 0,76 & 0,69 & 0,68 \\
\hline GBM 070402 & 3,43 & 1,14 & 0,73 & 0,43 & 1,09 & 0,71 & 0,44 \\
\hline GBM 070904 & 6,82 & 0,15 & 0,18 & 0,03 & * & 0,45 & $*$ \\
\hline GBM 070926A & 2,34 & 1,03 & 0,76 & 0,74 & 0,70 & 0,86 & 0,92 \\
\hline GBM 070926B & 1,66 & 1,39 & 1,16 & 0,99 & 1,24 & 0,93 & 1,26 \\
\hline GBM 071017A & 3,67 & 0,61 & 0,33 & 0,10 & 0,08 & 0,51 & 1,57 \\
\hline GBM 071017B & 5,14 & 4,50 & 3,09 & 2,32 & 1,38 & 2,28 & 3,29 \\
\hline GBM $071115 \mathrm{~A}$ & 5,55 & 0,32 & 0,42 & 0,28 & $*$ & 0,85 & $*$ \\
\hline
\end{tabular}

The relation factor $F$ represents the ratio of the expression of mRNA of the CDI33/prominin 1 to that of other markers in a and to cathepsins $B$, $L$ and $S$ and stefins $A$ and $B$ in $b$ in CD133 positive and negative cells. The cells were separated from primary GBM by magnetic separation, as described in Material and methods. All significantly altered values are in bold: $\mathrm{F} \geq 1.50$ means significantly higher levels of expression in CD133+ cells, $\mathrm{F} \leq 0.75$ means signficantly lower expression in CD133+ cells. (*) means that the levels were below the limit of detection. 
nant brain tumour glioblastoma (GBM). As in other studies ${ }^{36,37}$, rather variable amounts of these cells were obtained, ranging from $2 \%$ to $38 \%$. Further, we confirmed that the survival of GBM patients with higher CD133 mRNA expression was significantly shorter than in those with lower CD133 levels. Zeppernick et al. ${ }^{38}$ also found that both the proportion of CD133+ cells and their topological organization using immunohistochemitry (IHC), were prognostic factors for adverse, progressionfree survival and that the proportion of CD133+ cells was an independent risk factor for GBM regrowth. In a prospective study of GBM patients, it was demonstrated that CD133+/Ki67+ was a considerable prognostic factor of disease progression and poor clinical outcome. ${ }^{39}$ High CD133 expression in high-grade oligodendroglial tumours was reported to indicate shorter survival and to be more

FIGURE 4. 3D spheroid invasion assay. Spheroids were imbedded into collagen I and the invasion distance (panel A) and diameter (panel B) measured under the light microscope for up to 21 days. The average invasion distance was significantly higher $(p<0.05)$ for spheres of NNSC than for spheres of $\mathrm{NCH} 644$. The average spheroid size did not change significantly in NNSC, but increased ( $p=0.009$ ) in spheres of GBM stem cells, NCH644. GBM biopsy spheroids did not change in size and very few cells invaded the surrounding collagen. Panels $C, D$ and $E$ show the spheroids of NNCS, NCH644 cells and GBM spheroid, respectively at the start (upper panel) and after 21 days (lower panel) of the experiment.

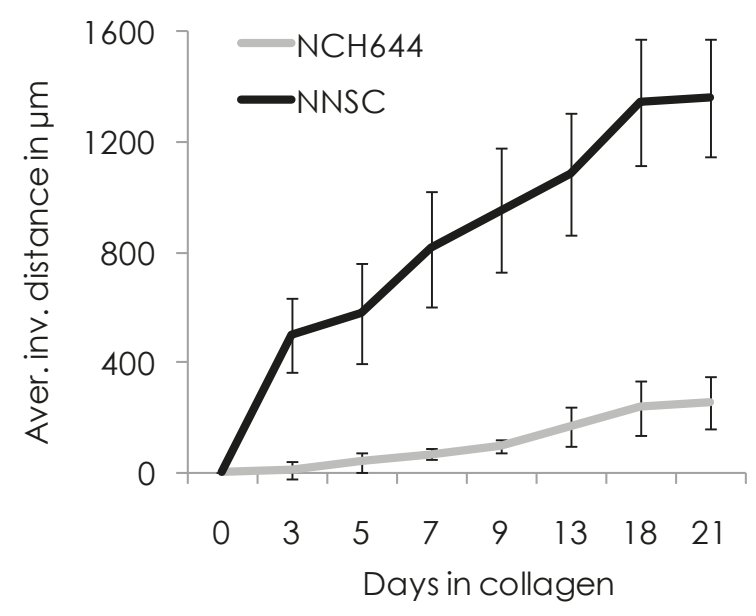

(A)

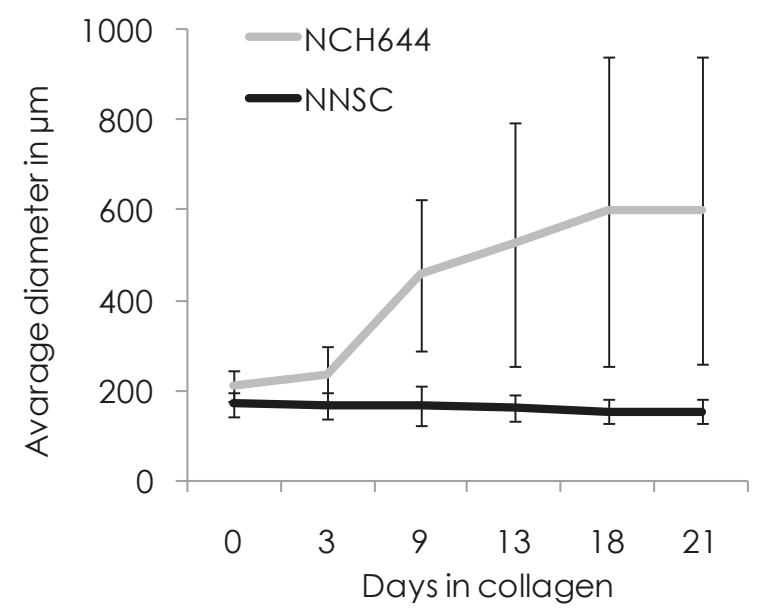

(B)
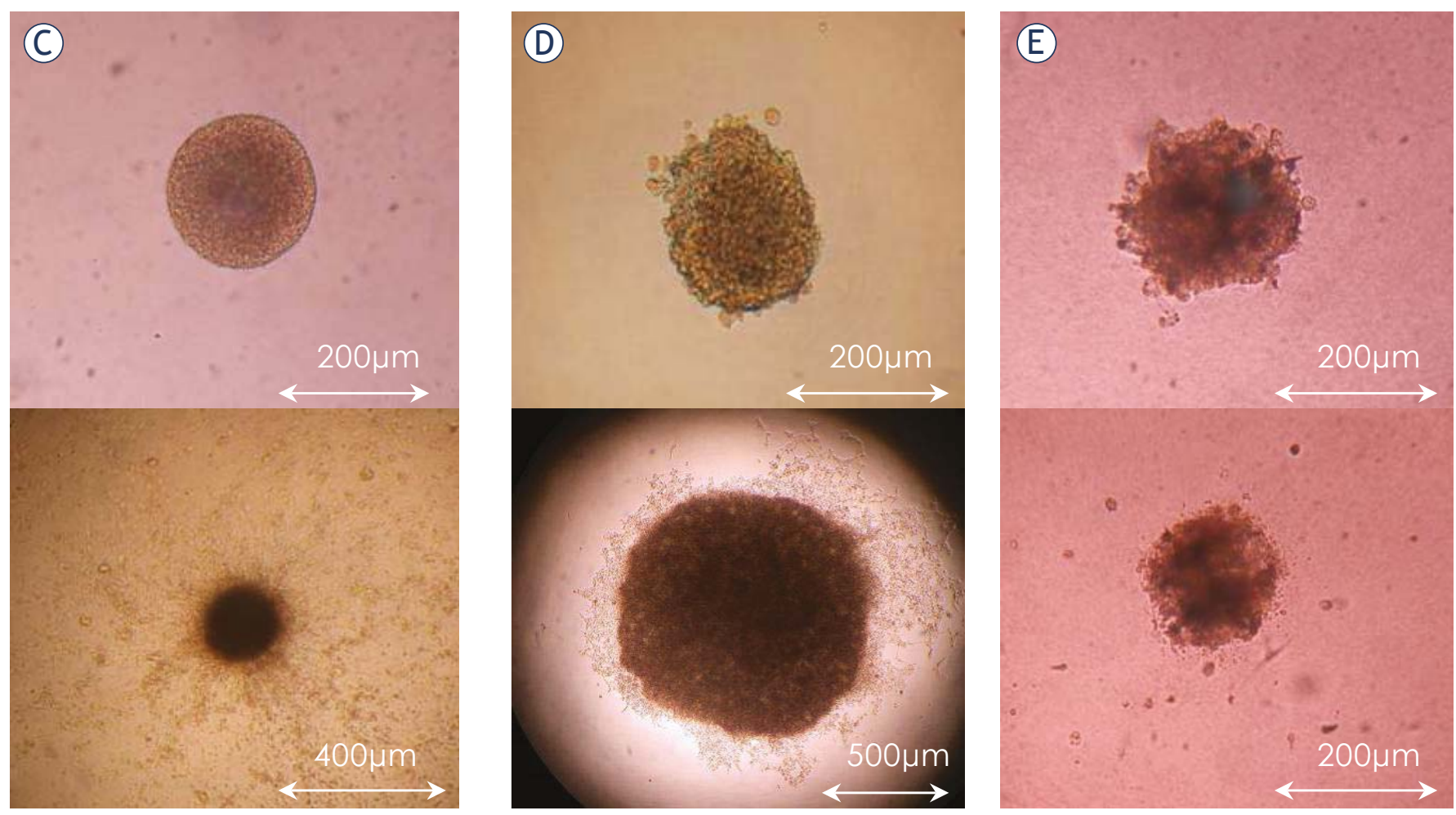
(A)
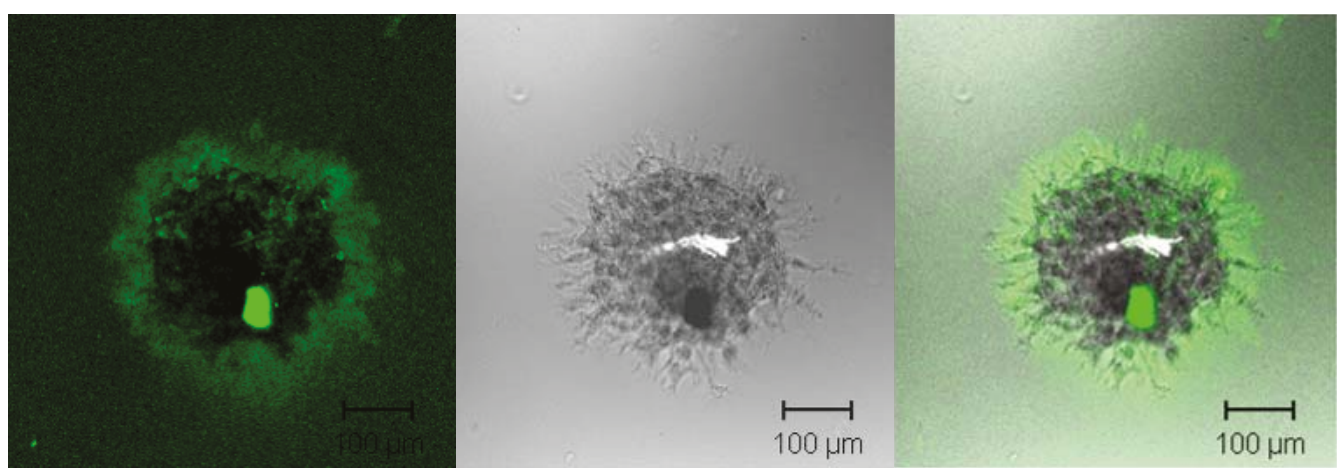

(B)
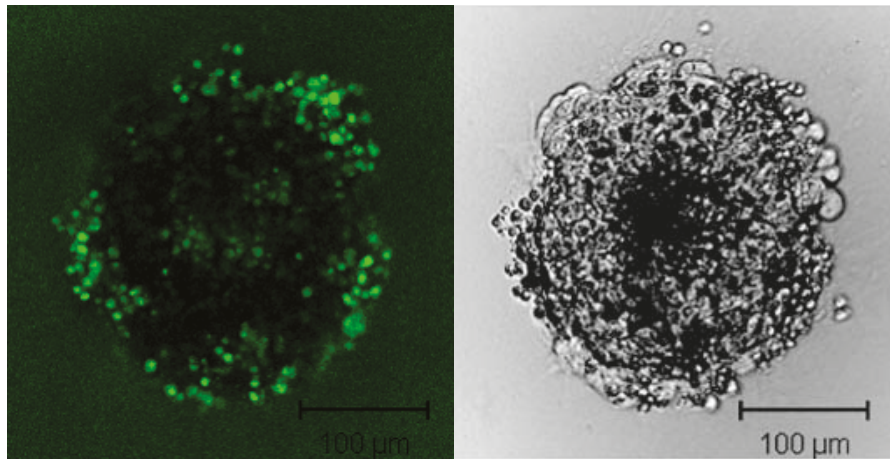

(C)
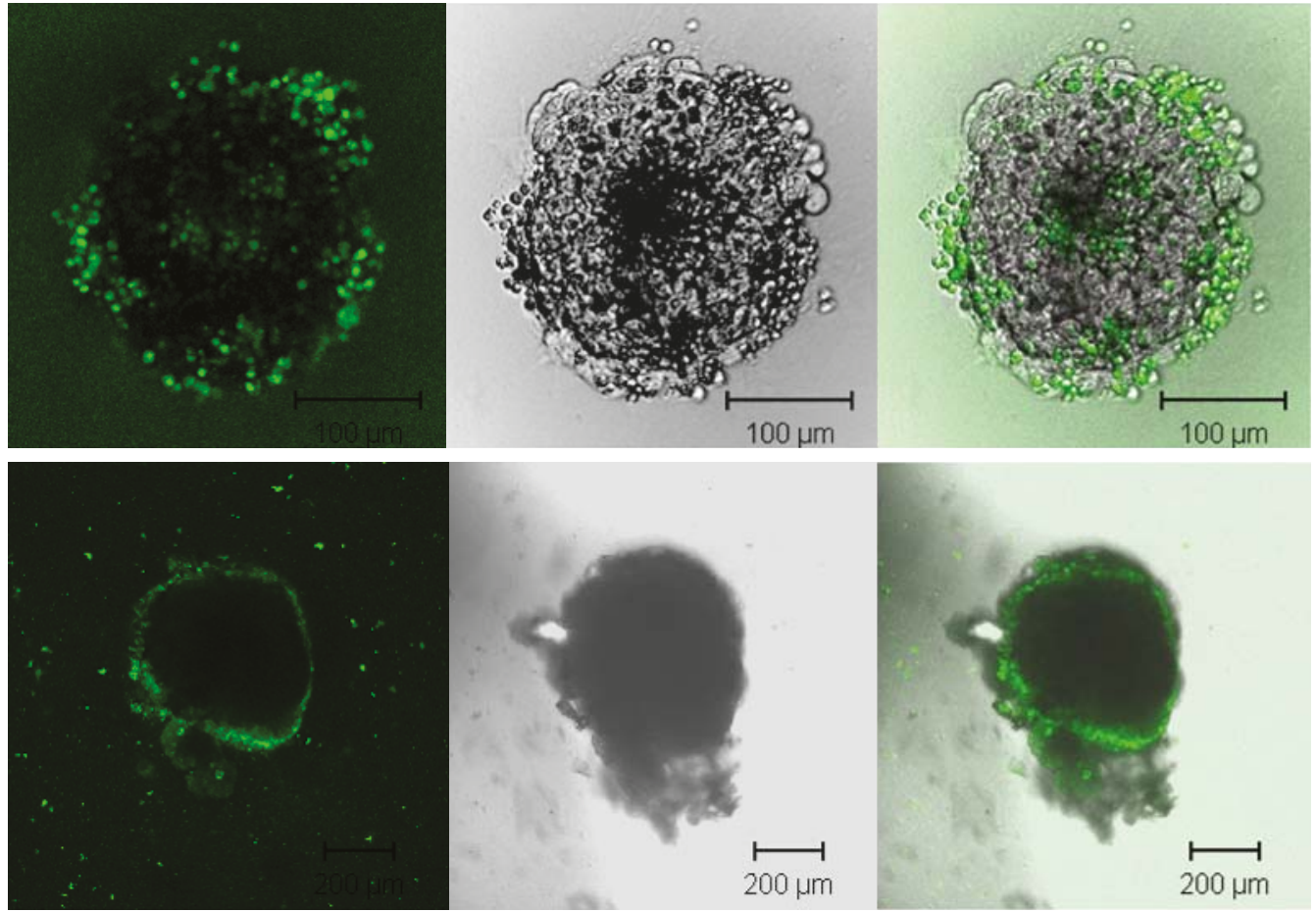

$100 \mu \mathrm{m}$

(D)

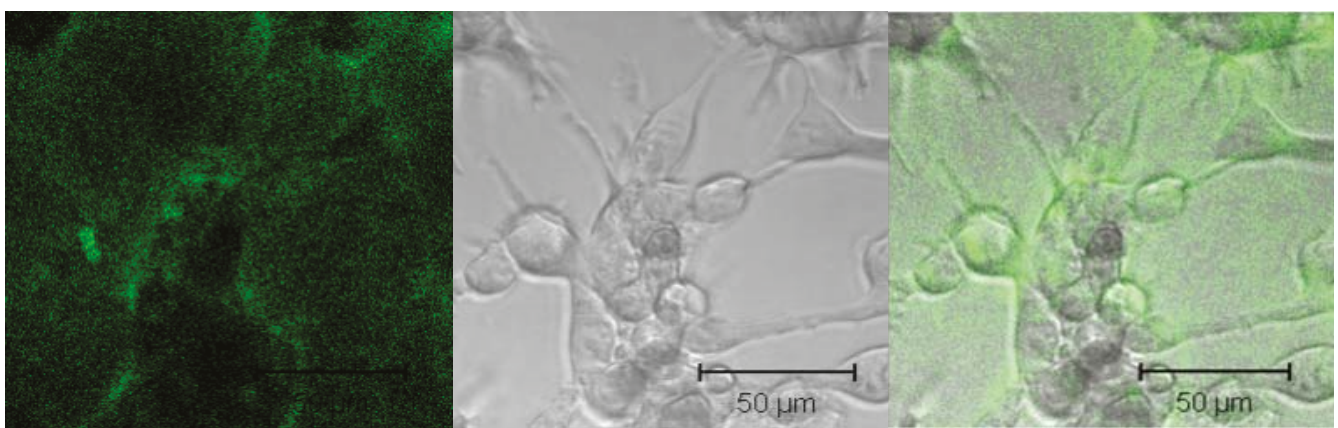

(E)

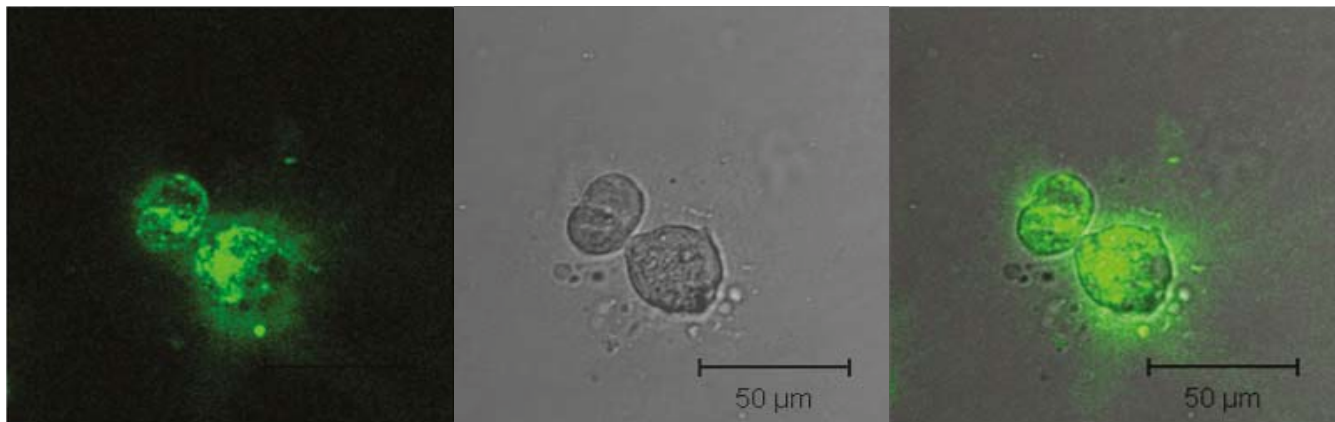

FIGURE 5. Matrix (DQ collagen) degradation by neurospheres and cells grown in monolayers. 1 \% (for neurospheres) and $2.5 \%$ (for the permanent cell lines grown in monolayers) DQ collagen type IV was added to Matrigel and matrix degradation observed after $24 \mathrm{~h}$. Left: green fluorescence of degraded DQ collagen under Zeiss LSMS10 confocal microscope. Middle: visual light images of the same areas. Right: green fluorescence and visual light images combined. A: Spheroid of normal neural stem cells NNSC, B: Spheroid of GBM stem cells NCH644, C: GBM spheroid, D: U87-MG cells and E: NHA cells. 
reliable than histological assessment. ${ }^{13}$ Although it was postulated that CD133 could not be evaluated so accurately by real-time $\mathrm{PCR}^{40}$ as by IHC, in our hands mRNA CD133 levels had a prognostic impact similar to that of CD133 protein expression in the above studies. We believe that the reliability was due to inclusion of a pre-amplification step in cell mRNA analysis because of the low levels of CD133 transcript.

Comparing CD133 expression with other differentiation markers and markers of lysosomal proteolysis in CD133+ cells, such as nestin and CatB, no correlation in the cohort of 13 GBM patients was found. In our previous studies nestin and Cat B correlated and were both highly prognostic, as proven by $\mathrm{IHC}^{23,41}$ and mRNA analysis. ${ }^{24}$ This indicates, therefore, that CD133 is a prognostic factor independent of nestin and cathepsins, indicating its specific biological impact on survival.

It has been postulated that cancer stem cells can develop a migratory phenotype and are responsible for the metastatic potential of tumours, such as colon carcinoma. ${ }^{8}$ In this study we questioned whether CD133+ stem cells are also responsible for the high invasiveness of GBM. Two dimensional (2D) invasion assays showed that the invasion of various normal and cancerous cells was not correlated to their expression of CD133. Being aware of the limits of $2 \mathrm{D}$ invasion assay ${ }^{25,42}$, we also monitored invasion distance and sphere diameter in a three dimensional (3D) invasion assay on spheres of NNSC, NCH644, NCH421k and GBM biopsy spheroids. Normal neurospheres were undoubtedly more invasive than the spheres of GBM stem cells. However, the latter were more proliferative, since the sphere diameter tripled within the first week of experiment, while it was shrinking in the spheres of NNSC. GBM spheroids also showed a more limited invasive potential than U87-GM spheroids ${ }^{25}$, most probably due to the heterogeneous cell population within tumour samples, with higher intercellular adhesion. In our hands, we found higher migratory potential of normal than cancerous spheroids and this was inversely related to CD133 expression, suggesting that its expression does not play a role in cell invasion.

However, according to a current hypothesis ${ }^{15}$, only tumour stem cells (also called tumour initiating cells) are capable of tumour renewal, therefore they must acquire migratory properties. Migratory stem cells were clearly visualised in the 3D assays and these cells may represent the invasive malignant GBM cell phenotype. However, there was no evidence that the migratory cell subpopulation of
CD133+ cell and GBM biopsy spheroids still expressed this marker. High plasticity of GBM tumour initiating (stem) cells with respect to CD133 expression was suggested, as not only CD133+11,38,43 but also CD133- spheroids ${ }^{15,32}$ were tumorigenic in animals. On the other hand, U87 cells which, when treated with neural stem cell medium, altered their phenotype towards more stem like cells, increasing the levels of CD133 and nestin, and induced highly infiltrative tumours in animals. ${ }^{44} \mathrm{~A}$ model has been proposed in which $\mathrm{CD}_{133^{+}}$cells constitute a noninvading GBM SC population with the potential to switch reversibly between an invasive and stationary phenotype. This involves an epithelial to mesenchymal transition, followed by a mesenchymal to epithelial transition when seeded to the secondary site. ${ }^{8}$ This transition, associated with reversible loss and gain of CD133 marker and possibly associated with a set of migratory proteins like Cats $(B, S)$, is an attractive hypothesis that could explain our results.

Here we have demonstrated for the first time that radial cellular migration from the spheres is accompanied by proteolysis of DQ collagen. Invasion of the cells was therefore associated with the activation of proteases required for matrix degradation. Presumably, cathepsins are involved in the initial steps of a proteolytic cascade ${ }^{45}$, leading to pericellular proteolysis, although alternative pathways of migration and interplay of proteases and inhibitors are possible. ${ }^{18,46,47}$ In high grade tumours higher expression of Cats B and S has been mostly linked to tumour invasion. ${ }^{18,19,22,30,48}$ We recently reported higher levels of all three Cats in invading than in non-invading cells separated from collagen embedded U87-MG spheroids, however only increased activation of CatB contributed to higher invasion. ${ }^{25}$ Here, significantly higher Cats levels were observed in the more migratory NNSC than in GBM NCH644 cells at mRNA levels. Normal neurospheres appear to migrate by extracellular dissolution of collagen matrix, whereas its degradation is to a greater extent intracellular within tumour cells, as suggested also for other tumor cells previously ${ }^{49}$ when compared with normal neural cells. This suggests that different modes of invasion may be associated with the different proteolysis pathways activated in normal and tumour cell migration. ${ }^{46}$

Inverse correlation of CD133 with invasion (Figure 3) corresponds to our clinical data, where we showed no correlation of Cat mRNA levels with CD133 and lower Cat activity in CD133+ cell fractions from GBM tumours. Cat activation in CD133cells may be explained by their up-regulation and/ 
or the downregulation of their inhibitors, such as cystatin $\mathrm{C}$ and/or stefins (A and $\mathrm{B})^{48}$, during the process of GBM stem cell differentiation. Similarly, CatB was reported to be upregulated after the differentiation of monocytes into tissue macrophages, but not earlier in hematopoetic differentiation ${ }^{49}$ and CatL expression was upregulated during angiogenesis from endothelial progenitor cells. ${ }^{50}$ These results suggest that GBM stem cells are not as invasive as their progenitors, losing CD133 and acquiring migratory properties by activation of a set of proteolytic enzymes, including Cats.

In conclusion, this study confirms that CD133 is a prognostic marker for survival of GBM patients. We have demonstrated that NNSC have higher invasion potential and invade the collagen matrix in a mode which differs from that of GBM initiating stem spheres. This result could have implications for designing new therapeutics, including protease inhibitors that may be specifically delivered by novel technologies, developing for drug delivery, to target invasive tumour stem cells. Increased expression of cathepsin activities in CD133 negative cells suggests their role in the invasive GBM stem cell progenitors.

\section{Acknowledgements}

The authors thank Dr. Maria Beatriz Duran Alonso for scientific and technical contributions to this work; Prof. Dr. Nobuhiko Katunuma, Japan, for providing CLIK-148; Prim. Dr. Jasna Šinkovec, Gynecology Clinic, University Medical Centre Ljubljana and Dr. Uroš Rajčević, National Institute of Biology, for samples of NNSC; Prof. Dr. Janko Kos, Faculty of Pharmacy, UL, Ljubljana, for the polyclonal and monoclonal antibodies for cathepsins, stefins and cystatin C; Dr. Marko Kreft, Medical Faculty, Ljubljana, for his help with confocal microscopy, and Dr. Roger Pain, UK-Slovenia, for critical reading of the manuscript. The project was supported by the Slovenian Research Agency Programme P1-0245 (granted to T.L.).

\section{References}

1. Louis DN, Ohgaki H, Wiestler OD, Cavenee WK, Burger PC, Jouvet A, et al. The $2007 \mathrm{WHO}$ classification of tumours of the central nervous system. Acto Neuropathol 2007; 114: 97-109.

2. Pilkington GJ. Cancer stem cells in the mammalian central nervous system. Cell Prolif 2005; 38: 423-33.
3. Baur M, Preusser M, Piribauer M, Elandt K, Hassler M, Hudec M. Frequent MGMT (0(6)-methylguanine-DNA methyltransferase) hypermethylation in long-term survivors of glioblastoma: a single institution experience. Radiol Oncol 2010; 44: 113-20.

4. Reya T, Morrison SJ, Clarke MF, Weissman IL. Stem cells, cancer, and cancer stem cells. Nature 2001; 414: 105-11.

5. Bjerkvig R, Tysnes BB, Aboody KS, Najbauer J, Terzis AJ. Opinion: the origin of the cancer stem cell: current controversies and new insights. Nat Rev Cancer 2005; 5: 899-904.

6. Huse JT, Holland EC. Targeting brain cancer: advances in the molecular pathology of malignant glioma and medulloblastoma. Nature Rev Cancer 2010; 10: 319- 31.

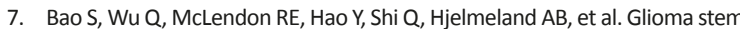
cells promote radioresistance by preferential activation of the DNA damage response. Nature 2006; 444: 756-9.

8. Brabletz T, Jung A, Spaderna SW, Hlubek F, Kirchner T. Migrating cancer stem cells - an integrated concept of malignant tumour progression. Nat Rev Cancer 2005; 5: 744-9.

9. Cheng JX, Liu BL, Zhang X. How powerful is CD133 as a cancer stem cell marker in brain tumors? Cancer Treat Rev 2009; 35: 403-8.

10. Singh SK, Clarke ID, Terasaki M, Bonn VE, Hawkins C, Squire J, et al. Identification of a cancer stem cell in human brain tumors. Cancer Res 2003; 63: 5821-8

11. Das S, Srikanth M, Kessler JA. Cancer stem cells and glioma. Nat Clin Pract Neurol 2008; 4: 427-35.

12. Joo KM, Kim SY, Jin X, Song SY, Kong DS, Lee Jl, et al. Clinical and biological implications of CD133-positive and CD133-negative cells in glioblastomas. Lab Invest 2008; 88: 808-15.

13. Beier $D$, Hau $P$, Proeschold $M$, Lohmeier $A$, Wischhusen J, Oefner $P J$, et al. CD133+ and CD133- glioblastoma-derived cancer stem cells show differential growth characteristics and molecular profiles. Cancer Res 2007; 67: 4010-5.

14. Wang J, Sakariassen $P \varnothing$, Tsinkalovsky O, Immervoll H, Bøe SO, Svendsen A et al. CD133 negative glioma cells form tumors in nude rats and give rise to CD133 positive cells. Int J Cancer 2008; 122: 761-8.

15. Prestegarden L, Svendsen A, Wang J, Sleire L, Skaftnesmo KO, Bjerkvig R, et al. Glioma cell populations grouped by different cell type markers drive brain tumor growth. Cancer Res 2010; 70: 4274-9.

16. Koblinski JE, Ahram M, Sloane BF. Unraveling the role of proteases in cancer. Clin Chim Acta 2000; 291: 113-35.

17. Lah TT, Durán Alonso MB, Van Noorden CJ. Antiprotease therapy in cancer: hot or not? Expert Opin Biol Ther 2006; 6: 257-79.

18. Gocheva V, Joyce JA. Cysteine cathepsins and the cutting edge of cancer invasion. Cell Cycle 2007; 6: 60-4.

19. Levicar N, Nutall RK. Lah TT. Proteases in brain tumour progression. Acto Neurochir 2003; 145: 825-38.

20. Vranic A. Antigen expression on recurrent meningioma cells. Radiol Oncol 2010; 44: 107-12.

21. Lah T, Obermajer N, Duran-Alonso MB, Kos J. Cysteine cathepsins and cystatins as cancer biomarkers. In: Edwards DR, editor. The cancer degradome: proteases and cancer biology. New York: Springer; 2008. p. 585-23.

22. http://www.merops.ec.uk

23. Strojnik T, Kavalar R, Trinkaus M, Lah $T$. Cathepsin L in glioma progression: comparison with cathepsin B. Cancer Detect Prev 2005; 29: 448-55.

24. Colin C, Voutsinos-Porche B, Nanni I, Fina F, Metellus PH, Intagliata D, et al. High expression of cathepsin B and plasminogen activator inhibitor type-1 are strong predictors of survival in glioblastomas. Acta Neuropathol 2009; 118: $745-54$.

25. Gole B, Durán Alonso MB, Dolenc V, Lah TT. Post-translational regulation of cathepsin B, but not other cysteine cathepsins, contributes to increase glioblastoma cell invasion in vitro. Pathol Oncol Res 2009; 15: 711-23.

26. Sivaparvathi M, Yamamoto M, Nicolson GL, Gokaslan ZL, Fuller GN, Liotta $L A$, et al. Expression and immunohistochemical localization of cathepsin $L$ during the progression of human gliomas. Clin Exp Metastasis 1996; 14: 27-34. 
27. Lah TT, Strojnik T, Levicar N, Bervar A, Zajc I, Pilkington G, et al. Clinical and experimental studies of cysteine cathepsins and their inhibitors in human brain tumors. Int J Biol Markers 2000; 15: 90-3.

28. Levičar N, Dewey RA, Daley E, Bates TE, Davies D, Kos J, et al. Selective suppression of cathepsin L by antisense CDNA impairs human brain tumor cell invasion in vitro and promotes apoptosis. Cancer Gene Ther 2003; 10 141-51.

29. Zajc I, Hreljac I, Lah T. Cathepsin L affects apoptosis of glioblastoma cells: a potential implication in the design of cancer therapeutics. Anticancer Res 2006; 26: 3357-64.

30. Flannery T, McQuaid S, McGoohan C, McConnell RS, McGregor G, Mirakhur $M$, et al. Cathepsin S expression: An independent prognostic factor in glioblastoma tumours-A pilot study. Int J Cancer 2006; 119: 854-60.

31. Kos J, Lah TT. Cystatins in cancer. In: Žerovnik E, Kopitar-Jerala N (eds) Human Stefins and Cystatins. New York: Nova Science Publishers Inc; 2006. p. $152-65$.

32. Sakariassen $P \varnothing$, Prestegarden $L$, Wang J, Skaftnesmo KO, Mahesparan $R$ Molthoff $C$, et al. Angiogenesis-independent tumor growth mediated by stem-like cancer cells. Proc Natl Acad Sci USA 2006; 103: 16466-71.

33. Palmer TD, Schwartz PH, Taupin P, Kaspar B, Stein SA, Gage FH. Progenitor cells from human brain after death. Nature 2001; 411: 42-3.

34. Campos B, Wan F, Farhadi M, Ernst A, Zeppernick F, Tagscherer KE, et al. Differentiation therapy exerts antitumour effects on stem-like glioma cells. Clin Cancer Res 2010; 16: 2715-28.

35. Demuth T, Rennert JL, Hoelzinger DB, Reavie LB, Nakada M, Beaudry C, et al. Glioma cells on the run - the migratory transcriptome of 10 human gliom cell lines. BMC Genomics 2008; 9: 54

36. Campos B, Herold-Mende CC. Insight into the complex regulation of CD133 in glioma. Int J Cancer 2010; 128: 501-10.

37. Wu Y, Wu PY. CD133 as a marker for cancer stem cells: progresses and concerns. Stem Cell Dev 2009; 18: 1127-34.

38. Zeppernick F, Ahmadi R, Campos B, Dictus C, Helmke BM, Becker N, et al. Stem cell marker CD133 affects clinical outcome in glioma patients. Clin Cancer Res 2008; 14: 123-9.

39. Pallini R, Ricci-Vitiani L, Banna GL, Signore M, Lombardi D, Todaro M, et al. Cancer stem cell analysis and clinical outcome in patients with glioblastoma multiforme. Clin Cancer Res 2008; 14: 8205-12.

40. Kong D-S, Kim MH, Park W-Y, Suh Y-L, Lee J-I, Park K, et al. The progression of gliomas is associated with cancer stem cell phenotype. Oncol Rep 2008 19: $639-43$

41. Strojnik T, Røsland GV, Sakariassen PO, Kavalar R, Lah Turnsek T. Neural stem cell markers, nestin and musashi proteins, in the progression of human glioma: correlation of nestin with prognosis of patient survival. Surg Neurol 2007; 68: 133-43.

42. Birgersdotter A, Sandberg R, Ernberg I. Gene expression perturbation in vitro-a growing case for three-dimensional (3D) culture systems. Semin Cancer Biol 2005; 15: 405-12.

43. Karcher $\mathrm{S}$, Steiner $\mathrm{HH}$, Ahmadi $\mathrm{R}$, Zoubaa $\mathrm{S}$, Vasvari $\mathrm{G}$, Bauer $\mathrm{H}$ et Different angiogenic phenotypes in primary and secondary glioblastomas. Int J Cancer 2006; 118: 2182-9.

44. Yu SC, Ping YF, Yi L, Zhou ZH, Chen JH, Yao XH, et al. Isolation and characterization of cancer stem cells from a human glioblastoma cell line U87. Cancer Lett 2008; 265: 124-34.

45. Schmitt $M$, Jaenicke $F$, Graeff $H$. Protease, matrix degradation and tumour cell spread. Fibrinolysis 1992; 6: 1-17.

46. Friedl $P$, Wolf $K$. Tumour cell invasion and migration. Diversity and escape mechanisms. Nat Rev Cancer 2003; 3: 362-74.

47. Zajc I, Bervar A, Lah Turnšek T. Cysteine cathepsins, stefins and extracellular matrix degradation during invasion of transformed human breast cell lines. Radiol Oncol 2006; 40: 259-71.

48. Strojan P. Cysteine cathepsins and stefins in head and neck cancer: an update of clinical studies. Radiol Oncol 2008; 42: 69-81.

49. Berquin LM, Sloane BF. Cathepsin B expression in human tumours. Adv Exp Med Biol 1996; 389: 281-94.
50. Urbich C, Heeschen C, Aicher A, Sasaki K, Bruhl T, Farhadi MR, at al. Cathepsin $\mathrm{L}$ is required for endothelial progenitor cell-induced neovascularization. Nat Med 2005; 11: 206-13. 